\title{
Asociación del polimorfismo genético del locus HLA-G y la susceptibilidad a contraer lupus eritematoso sistémico expresada en algunas manifestaciones clínicas
}

\section{Association of the HLA-G locus genetic polymorphism and the susceptibility to contract systemic \\ lupus erythematosus expressed in some clinical manifestations}

\author{
Guerra-Monrroy Gabriela $(\mathbb{D} *$, Sosa-Tordoya Luis Fernando
}

\begin{tabular}{|c|}
\hline Data of the Article \\
\hline $\begin{array}{l}\text { University Mayor de San Andrés. } \\
\text { Faculty of Pharmaceutical and Biochemical } \\
\text { Sciences. } \\
\text { Institute of Laboratory Services for Diagnosis and } \\
\text { Health Research. } \\
\text { Avenue Saavedra } 2224 \text {. } \\
\text { La Paz-Plurinational State of Bolivia } \\
\text { Tel: +591 222-2436 222-4895 }\end{array}$ \\
\hline $\begin{array}{l}\text { * Contact address: } \\
\text { University Mayor de San Andrés. } \\
\text { Faculty of Pharmaceutical and Biochemical } \\
\text { Sciences. } \\
\text { Institute of Laboratory Services for Diagnosis and } \\
\text { Health Research. } \\
\text { Avenue Saavedra } 2224 \text {. } \\
\text { La Paz-Plurinational State of Bolivia } \\
\text { Mobile: }+59170559199\end{array}$ \\
\hline $\begin{array}{l}\text { Gabriela Guerra-Monrroy } \\
\text { E-mail address: gabagmonrroy@gmail.com }\end{array}$ \\
\hline
\end{tabular}

\section{Palabras clave:}

Lupus eritematoso sistémico,

HLA-G,

polimorfismo,

autoinmunidad,

asociación genética,

complejo mayor de histocompatibilidad.

\section{Resumen}

La susceptibilidad individual en autoinmunidad puede estar determinada por una combinación de polimorfismos específicos de genes que codifican para múltiples proteínas, citoquinas, antígenos del complejo principal de histocompatibilidad, moléculas de adhesión, y proteínas celulares. Esta condición puede conducir a la expresión anormal de moléculas inmunoreguladoras y finalmente resultar en el desarrollo o exacerbación de la enfermedad autoinmune. HLA-G es una molécula glicoprotéica del MHC de clase I, la cual cumple con funciones muy importante al momento de activar y regular el sistema inmune. Por lo tanto, lo que se pretende con este estudio es determinar la asociación genética entre el polimorfismo de 14 pb del gen HLA-G con la susceptibilidad a contraer LES y las manifestaciones clínicas de la enfermedad.

La población de estudio consistió de 120 pacientes con LES y 112 pacientes sin la enfermedad (grupo control), 94\% procedía de la ciudad de La Paz, quienes asistieron al Instituto SELADIS. Para el estudio se obtuvo el DNA humano a partir de sangre periférica, se realizó la PCR para la tipificación molecular de los genotipos y alelos que fueron revelados por medio de electroforesis en gel de agarosa. Al mismo tiempo se realizaron pruebas serológicas por ELISA para determinar la presencia de anticuerpos IgG anti-DNA de doble cadena en los pacientes lúpicos. Los resultados de la PCR mostraron que los pacientes lúpicos tienen mayor frecuencia de expresión del genotipo Ins/Del $(\mathrm{OR}=1.72$, p $<0.05)$; mientras que, la presencia del genotipo homocigoto Ins/Ins es más frecuente en el grupo control $(\mathrm{OR}=0.29, \mathrm{p}<0.001)$, mostrándose de esta forma que el primer genotipo es un factor de riesgo y el segundo, un factor de protección a padecer LES respectivamente. Se observó también que entre pacientes y controles no existe diferencia significativa en la frecuencia de presentación del genotipo Del/Del en homocigosis. En cuanto a las frecuencias alélicas se obtuvo que el alelo deleción en más frecuente en el grupo de pacientes lúpicos, a comparación del grupo control donde ambos alelos presentaron el mismo porcentaje. Con respecto a las manifestaciones clínicas se observó que el polimorfismo Ins/Del (O.R=8.64) es factor de riesgo para el desarrollo de manifestaciones dermatológicas.

2020. Journal of the Selva Andina Research Society®. Bolivia. Todos los derechos reservados.

\section{Abstract}

Autoimmune diseases such as systemic lupus erythematosus (SLE) are characterized by inflammation, as well as the progressive development of antibodies and T lymphocytes directed against self antigens. Although the etiology is still unknown, it is known that there is a strong genetic association between these diseases and some alleles and / or haplotypes of the major histocompatibility complex (MHC).

Individual susceptibility in autoimmunity may be determined by a combination of gene-specific polymorphisms that code for multiple proteins, cytokines, adhesion molecules, among others, and that is why it is important to study them.

HLA-G is an MHC class I glycoprotein molecule, which performs very important functions when activating and 
regulating the immune system. Therefore, what this study intends is to determine the genetic association between the 14 bp polymorphism of the HLA-G gene with the susceptibility to contract SLE and the clinical manifesta-

\section{Record from the article.}

Received march 2020

Returned may 2020.

Accepted june 2020

Available online, august 2020

\section{Edited by:}

Selva Andina

Research Society

Keywords:

Systemic lupus erythematosus,

HLA-G,

polymorphism,

autoimmunity,

genetic association,

major histocompatibility complex. tions of the disease.

The study population consisted of 120 patients with SLE and 112 patients without the disease. For the study, human DNA was obtained from peripheral blood, PCR was performed for molecular typing of the genotypes and alleles that were revealed by means of electrophoresis. in agarose gel. At the same time, serological tests were carried out using the ELISA technique to determine the presence of double-chain anti-.DNA IgG antibodies. The PCR results showed that lupus patients have a higher frequency of expression of the Ins/Del genotype (OR = $1.72, \mathrm{p}<0.05$ ); while, the presence of the homozygous Ins/Ins genotype is more frequent in the control group $(\mathrm{OR}=0.29, \mathrm{p}<0.001)$, thus showing that the first genotype is a risk factor and the second, a protection factor to suffer SLE respectively. It was also observed that between patients and controls there is no significant difference in the frequency of presentation of the Del/Del genotype in homozygosity. Regarding allele frequencies, the deletion allele was found to be more frequent in the group of lupus patients, compared to the control group where both alleles presented the same percentage. Regarding the clinical manifestations, it was observed that the Ins/Del polymorphism $(\mathrm{OR}=8.64)$ is a risk factor for the development of dermatological manifestations.

\section{Introduction}

The systemic lupus erythematosus (SLE), an autoimmune disease (IAS), inflammatory of unknown etiology, which organs, tissues and cells are damaged by deposition of immune complexes and various autoantibodies directed against a broad spectrum of nuclear and cytoplasmic antigens, presenting multiple clinical manifestations and compromise of one or more organs and systems, characteristic of the disease ${ }^{1-3}$.

One of the main characteristics of SLE is the production of autoantibodies against autoantigens and the formation of immunocompetes that mediate inflammatory responses when deposited in various organs and tissues ${ }^{4}$. While etiology is not entirely clear, it is known what genetic and environmental factorsmay be involved in the emergence of the great diversity of autoantibodies, which together with the variability of clinical manifestations can occur from very mild to severe forms, which can even compromise the life of the patient ${ }^{5,6}$.

One of the environmental factors linked to SLE is ultraviolet radiation, which causes exacerbation in
$70 \%$ of patients by increasing the apoptosis of keratinocytes and other cells, or altering DNA, intracellular proteins so that they become antigen$\mathrm{ic}^{2,7,8}$.

The great clinical heterogeneity, association of clinical manifestations with the different antibodies suggest that LES can be divided into different subgroups, with great importance in pathogenesis, therapy and prognosis of the disease. However, the characterization of multiple SLE patterns is complex, mainly when looking at small groups of patients with high ethnic heterogeneity ${ }^{9-11}$.

A study in African American women shows strong associations between genetic factors with SLE, the variants located in the major histocompatibility complex (MHC), on the short arm of chromosome 6 (6p21.3), which contains hundreds of genes, many of them with immune functions. Before the advent of genome-wide association studies (GWAS), serological types of human leukocyte antigen (HLA) genes were revealed to be associated with the risk of SLE. In particular, HLA class II HLA-DRB1 * 1501 
and HLA-DRB * 0301, alleles have been consistently reported to be associated with the risk of SLE in populations of European descent and these alleles confer a number, up to three times the risk of $\mathrm{SLE}^{12}$. The Latin American Group for the Study of Lupus Erythematosus (GLADEL) carried out the study of genomic linkage in SLE, among them a metaanalysis identified three chromosomal regions that show the most consistent evidence of linkage: 6p21.1-q15, 20p11-q13.13 and 16p13-q12.2 ${ }^{13-16}$

The HLA-G gene belongs to the family of nonclassical histocompatibility molecules located on chromosome $6(6 \mathrm{p} 21.3)^{17,18}$. The sequence and the HLA-G gene are very similar to the classic HLA class I genes, it has 8 exons, 7 introns, except by a stop codon in exon 6 that differs from the others. Throughout their study, it was possible to show that the function of the HLA-G molecule is to induce tolerance on innate cellular responses and adaptive, as an example, in cytokine induction, is able to inhibit NK cell activity and decrease cytotoxic $\mathrm{T}$ lymphocytes during the $\mathrm{T}$ cell proliferation response in the allogeneic primary reaction, suggesting a pathophysiological role of said HLA molecule in inflammatory, autoimmune, viral diseases, tumors and transplants ${ }^{19-23}$.

The HLA-G gene takes seven protein forms or isoforms, which are the result of the alternative splicing of HLA-G messenger RNA (mRNA), four correspond to molecules that are expressed on the cell membrane (HLA-G1, G2, G3 and G4) and three soluble molecules (HLA-G5, G6 and G7) ${ }^{19,20,24,25}$.

In contrast to the extensive polymorphism of the classic HLA class I genes (HLA-A, B and C locus), it has been considered low in polymorphism at the HLA-G locus, presenting a limited sequence heterogeneity and with few alleles described, 61 alleles to date ${ }^{17,21,22}$.
The membrane-bound HLA-G protein is selectively expressed in placental extraphobic trophoblast cells, fetal endothelial cells, macrophages of the chorionic villus mesenchyme, and epithelial cells of the thymus medulla ${ }^{18,19,22,26}$. However, low levels of HLA-G gene transcription have been detected in some adult tissue cells, such as $\mathrm{T}$ and $\mathrm{B}$ lymphocytes. Furthermore, HLA-G mRNA expression has been observed at sites such as the anterior region of the eye, skin, lungs, in kidney cells, ovary, colon and intestine $\mathrm{e}^{20,25,27}$.

HLA-G also exhibits polymorphisms in introns, the promoter region, and the untranslated region (3'UTR). The latter consists of the 14 base pair (bp) insertion/ deletion (Ins/Del) that is present in exon $8^{28}$. This Ins/Del polymorphism has been associated with instability of HLA-G mRNA and lower levels of soluble HLA-G (sHLA-G) in serum from healthy subjects. This polymorphism is being widely studied in inflammatory diseases, especially in SLE and rheumatoid arthritis (RA) $)^{24,25,28,29}$.

Authors such as Consiglio et al. ${ }^{24}$, Rizzo et al. ${ }^{19}$, $\mathrm{Wu}$ et al. $^{28}$, Cavalcanti et al. ${ }^{20}$, carried out similar studies in different populations, determined that if there was a genetic association between the Ins/Del polymorphism and the risk of suffering SLE, reflecting different results depending on the region ethnic. In Bolivia, a similar study has not been conducted to evaluate the potential that this gene has in predicting the risk of the disease or in predicting the organic consequences that the disease can produce in Bolivian patients.

The data of the present study will provide a significant contribution, the reported findings may contribute to predictive medicine in patients at risk of suffering from the disease or who already suffer from it.

Given the socio-economic impact of this disease and in order to contribute to the field of preventive 
and personalized medicine, the present work aims to determine to what extent the Ins/Del $14 \mathrm{bp}$ poly morphism existing in exon 8 of the gene HLA-G is associated with the risk of suffering SLE and / or any of its clinical manifestations in a population of Bolivian patients who attended the SELADIS Institute during 2015 and 2016.

\section{Materials and methods}

This research work corresponds to a case control study, carried out during the months of January 2015 to April 2016 at the Histocompatibility and Immunogenetics Laboratory (LHI) of the Institute of Laboratory Services for Diagnosis and Health Research (SELADIS). We worked with 232 patients, they were divided into two groups, which correspond to lupus patients (PL) (120) and control group (GC) (112), all were accepted under the following inclusion and exclusion criteria:

Inclusion criteria. People of any gender, of legal age who meet at least four of the eleven criteria for the diagnosis of SLE established by the American College of Rheumatology $(\mathrm{CAR})^{30}$, who have confirmed the disease through the clinic and laborato$\mathrm{ry}^{31}$. In the case of the 2 patients under the age of 18 (12 and 16 years respectively), the consent of their father, mother, guardian or attorney was requested to incorporate them into the study.

Exclusion criteria. Those patients who presented other autoimmune pathologies in addition to SLE. All people whose treating physicians disagreed were excluded from the study, with their patients participating in the study. I also know excluded all family members of LP from the study because this is not a study of genetic linkage analysis using family segregation.

65
Elimination criteria. Patients who, after being involved in the study decide not to be part of the study, were excluded from the study, nor were the data obtained taken into account in the study final analysis of results. Patients who, after having accepted their participation, did not attend the sampling.

Control group

Inclusion criteria. Patients of any age and sex who were ruled out the presence of SLE or other autoimmune diseases and who signed the informed consent.

Exclusion criteria. To people who presented family history of autoimmune diseases. All the participants were informed verbally and in writing about the study, having signed an informed consent. The 120 PLs had an average age of 37 years (range) years and a female: male ratio of 16: 1 who attended the SELADIS Institute in the city of La Paz. All patients included in the study met at least 4 of the 11 classification criteria including three clinical criteria and an immunological criterion, proposed by CAR for patients with SLE $^{30,32}$, a clinical history (HC) was performed in order to apply the inclusion and exclusion criteria, Data were also collected on the clinical manifestations that occurred from the beginning of their disease. All patients underwent the test to determine anti-double-stranded DNA antibodies, which were analyzed by the immunoenzymatic technique (ELISA) ${ }^{30}$.

All SLE patients underwent genotyping for the 14 bp Ins / Del polymorphism located in exon 8 of the HLA-G gene ${ }^{24}$.

The 112 volunteers from the control group that participated in the study were of Bolivian nationality $95.5 \%$ were from the city of La Paz, with an average age of 28 years, in the same way they were genotyped for the 14 bp polymorphism of the 
HLA-G gene ${ }^{24}$.

Genomic DNA extraction. Genomic DNA was extracted from peripheral blood samples using the commercial kit (FAVORGEN Biotech Corp USA) which uses columns with membrane of silica in the presence of chaotropic salts ${ }^{33}$.

The DNA obtained was then quantified using UV spectrometry, which allowed obtaining a DNA concentration in the range of 50 to $200 \mathrm{ng} / \mu \mathrm{L}$ and a DNA purity between 1.5 and 1.8 , which determined the yield and purity ${ }^{34}$.

Genotyping of the 14 bp polymorphism in exon 8 ( $3^{\prime}$ UTR) of the HLA-G gene. The HLA-G polymorphism is genotyped using the polymerase chain reaction (PCR), under the following conditions: preheating at $94^{\circ} \mathrm{C}$ for $2 \mathrm{~min}$, denaturation in 35 cycles at $34{ }^{\circ} \mathrm{C}$ for $30 \mathrm{~s}, 64{ }^{\circ} \mathrm{C}$ for $60 \mathrm{~s}$ and $72{ }^{\circ} \mathrm{C}$, for $60 \mathrm{~s}$, final extension of $72{ }^{\circ} \mathrm{C}$ for $10 \mathrm{~min}^{19}$.

The preparation of the Master Mix was carried out in $25 \mu \mathrm{L}$ of final volume: Buffer $1 \mathrm{X}$, dNTP 0.2 $\mathrm{mM}, \mathrm{MgCl} 21.5 \mathrm{mM}$, Taq DNA polymerase $0.75 \mathrm{U}$ and $10 \mathrm{pmol}$ of each primer (forward 5 GTGATGGGCTGTTTAAAGTGTCACC-3' and reverse 5'-GGAAGGAATGCAGTTCAGCATGA$3^{-19}$.

Once the genetic material was obtained and amplified, the DNA bands were developed for which the 5\% agarose gel electrophoresis was carried out using the $1 \mathrm{X}$ TBE buffer (Tris, Boric Acid and EDTA) for $150 \mathrm{~mL}$ and the nucleic acid intercalant SYBR Green $7 \mathrm{uL}$ at $10,000 \mathrm{X}^{35}$.

Statistical analysis. The statistical package SSPS 22.0 Trial version was used, it was possible to obtain all the allelic and genotypic frequencies. The Odd Ratio (O.R) was used for the degree of association and chi-square using a $95 \%$ confidence inter$\mathrm{val}^{36}$.

From the data obtained from the PCR, the alleles and genotypes of the HLA-G gene presented by the two groups studied were assigned. The study also identified the signs and symptoms most frequently reported by patients during their illness in order to establish the existence of a possible association between allelic and genotypic frequencies of the HLA-G polymorphism with clinical manifestations reported, figure 1 most reported signs and symptoms.

Figure 1 Most frequent signs and symptoms reported by patients during their illness

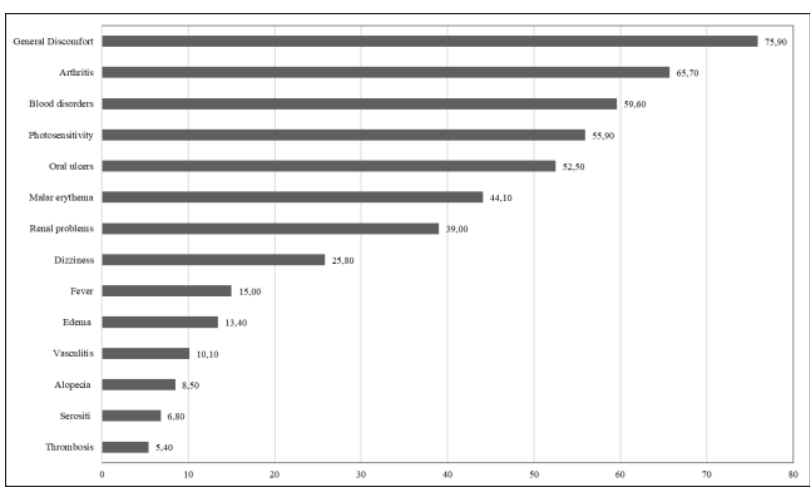

The most frequent signs and symptoms reported by patients during their illness were: general malaise (75.9\%), arthritis (65.7\%), blood problems $(59.6 \%)$, oral ulcers $(52.5 \%)$, malar erythema $(44.1 \%)$ and kidney problems (39\%). In a majority of cases, the initial condition was multisystemic (more than one clinical sign or symptom at the same time), which made their initial diagnosis difficult.

\section{Results}

From the genotypic and allelic frequencies obtained from the two sample groups studied, the analysis of the genetic association for each allele of the gene studied could be performed. Analysis by PCR, it can be seen (figure 2) that LPs have a higher frequency of expression of the Ins/Del genotype since 
61 of 120 patients (50.8\%) presented it, like the Del allele, observing its elevated increase. While, in the case of controls, although there are a greater number of cases with the Ins/Del genotype (37.55\%), no significant value is observed. It was also observed that between patients and controls there is no significant difference in the frequency of presentation of the Del/Del genotype in homozygosity.

Figure 2 Genotypic and allelic frequencies obtained for the association of the HLA-G locus polymorphism in patients

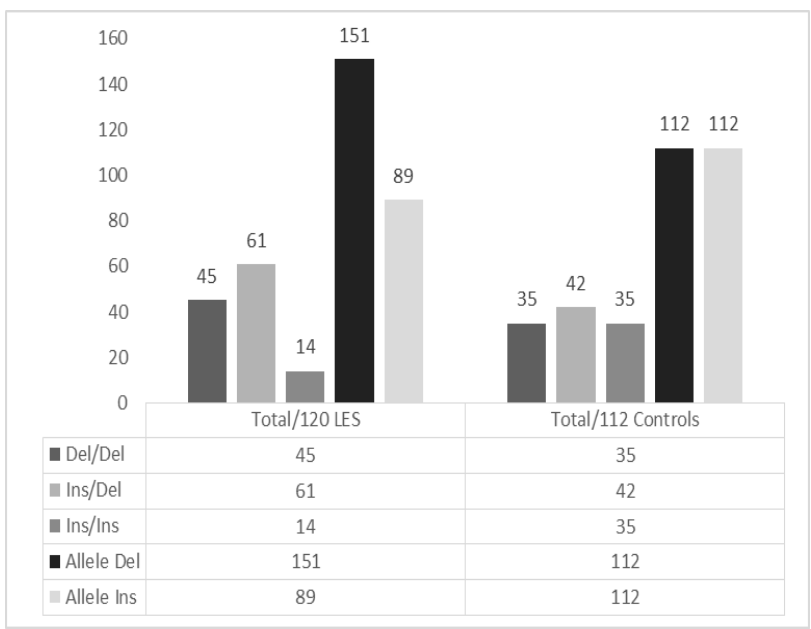

Regarding allele frequencies, it can be seen that the Del allele is more frequent in the PL group (62.9\%) compared to the $\mathrm{CG}$, in which both alleles were presented in the same percentage $(50 \%)$.

Regarding the Del allele, this presents a significant association of risk to SLE with an O.R of 1.70 (p = 0.005), unlike the Ins allele that presents a significant association of protection to LES with an O.R of $0.59(p=0.005)$.

On the other hand, the study sought to establish the existence of a possible association between the allelic and genotypic frequencies of the HLA-G polymorphism with the reported clinical manifestations by the PL, the results of this analysis can be seen in table 2. The Ins/Del polymorphism is highlighted as a risk factor for dermatological manifestations, since it presents an OR of $8.64(\mathrm{p}=0.001)$, contrary to Observe that the Del/Del and Ins/Ins polymorphisms are protection factors for the PLs due to their OR values of 0.25 and 0.30 respectively.

Hematological manifestations associate Del/Del polymorphism as a risk factor, since it presents an O.R value of 2.75 and Del/Ins polymorphism would become a protective factor with a O.R of

Table 1 Odds Ratio (O.R), confidence intervals and Chi square (X2) obtained for the association of the HLA-G Locus polymorphism between patients - controls and possible susceptibility to SLE

\begin{tabular}{llll}
\hline Polymorphism HLA-G & & \multicolumn{2}{l}{ Chi-squared } \\
\hline & O.R $($ IC $)$ & Value & Value-p \\
\hline Del/Del & $1.32(0.77-2.27)$ & 1 & 0.31691 \\
Ins/Del & $\mathbf{1 . 7 2}(\mathbf{1 . 0 2}-\mathbf{2 . 9 1})$ & 4.17 & 0.0411 \\
Ins/Ins & $\mathbf{0 . 2 9}(\mathbf{0 . 1 5}-\mathbf{0 . 5 8})$ & 13.34 & 0.00026 \\
Allele Del & $1.17(1.17-2.46)$ & 7.87 & 0.00502 \\
Allele Ins & $0.59(0.41-0.85)$ & 7.87 & 0.0502 \\
\hline
\end{tabular}

Table 1 highlights that there are significant data regarding the Ins/Del heterozygous polymorphism that presents a significant association of risk to SLE with a probability ratio $(\mathrm{OR})$ value of $1.32(\mathrm{p}=$ 0.04) unlike the Ins/Ins polymorphism representing a protection association to SLE with an OR of 0.29 $(\mathrm{p}=0.005)$.

Table 2 Association of the genotypic frequencies of the HLA-G polymorphism of lupus patients with the clinical manifestations reported in the course of their disease 


\begin{tabular}{|c|c|c|c|c|c|c|c|c|c|}
\hline \multicolumn{2}{|c|}{ Polymorphism } & \multicolumn{2}{|c|}{ Allele Present } & \multicolumn{3}{|c|}{ Chi-squared } & \multirow[b]{2}{*}{$\begin{array}{ll}\text { I.C. } & \text { high } \\
95 \% & \end{array}$} & \multirow[b]{2}{*}{ Value } & \multirow[b]{2}{*}{ Value-p } \\
\hline Clinical manifestations & HLA-G & $\begin{array}{l}\text { Present } \\
\text { clinic }\end{array}$ & $\begin{array}{l}\text { Absent } \\
\text { clínic }\end{array}$ & Odds Ratio & $\begin{array}{l}\text { I.C. } \\
\text { 95\% }\end{array}$ & low & & & \\
\hline \multirow[t]{3}{*}{ Renal } & Del/Del & 12 & 30 & 2.22 & 0.88 & & 5.61 & 2.91 & 0.0880 \\
\hline & Ins/Del & 8 & 48 & 0.48 & 0.18 & & 1.24 & 2.37 & 0.1236 \\
\hline & Ins/Ins & 3 & 23 & 0.90 & 0.23 & & 3.47 & 0.02 & 0.8782 \\
\hline \multirow[t]{3}{*}{ Dermatological } & Del/Del & 8 & 38 & 0.25 & 0.10 & & 0.60 & 10.1 & 0.0014 \\
\hline & Ins/Del & 29 & 16 & 8.64 & 3.68 & & 20.3 & 24.4 & 0.0000 \\
\hline & Ins/Ins & 5 & 24 & 0.30 & 0.11 & & 0.87 & 5.30 & 0.0213 \\
\hline \multirow[t]{3}{*}{ Hematologic } & Del/Del & 18 & 25 & 2.75 & 1.21 & & 6.22 & 6.04 & 0.0140 \\
\hline & Ins/Del & 12 & 46 & 0.43 & 0.19 & & 0.98 & 4.38 & 0.0364 \\
\hline & Ins/Ins & 4 & 15 & 0.63 & 0.19 & & 2.06 & 0.59 & 0.4427 \\
\hline \multirow[t]{3}{*}{ Cardiopulmonary } & Del/Del & 5 & 47 & 0.93 & 0.28 & & 3.11 & 0.02 & 0.9023 \\
\hline & Ins/Del & 4 & 36 & 1.00 & 0.28 & & 3.54 & 0.00 & 1.0000 \\
\hline & Ins/Ins & 3 & 28 & 0.99 & 0.25 & & 3.91 & 0.00 & 0.9862 \\
\hline
\end{tabular}

\section{Discussion}

SLE is a disease of very complex etiology in which genetic factors are part of the etiopathogenesis, being confirmed by highly complex genetic studies such as the GWAS ${ }^{12}$ analysis that was previously discussed, as well as family aggregation studies, the genetic association is reflected in a meta-analysis, where it was shown that autoimmune diseases prevail in families, the most important being the addition of autoimmune thyroid disease followed by SLE and $\mathrm{RA}^{13,37}$.

The frequency of SLE is increasing, mainly because more and more cases of this disease are detected. Incidence and prevalence rates differ depending on race and country or geographic area ${ }^{4}$. The prevalence in the general population, depending on the area, is between 4 and 250 cases per 100000 inhabitants: in North America, Asia and Northern Europe it affects 40 out of every 100000 inhabitants, with a higher incidence among the population hispanic and African American ${ }^{4}$. In Bolivia, the Ministry of Health does not have related and official data on the prevalence or incidence of the disease. Unofficial data, such as those reported by the LHI of the
SELADIS Institute, report that an annual average of 130 new cases of lupus are confirmed in the department of $\mathrm{La} \mathrm{Paz}$, and $90 \%$ of patients are women of childbearing age $\mathrm{e}^{38}$.

As in its genetic complexity, SLE also presents great heterogeneity with respect to clinical manifestations and the presence of autoantibodies. This fact implies the need for analysis of the genetic factors that determine the expression of the disease in different groups, in order to obtain more concrete results that manage to provide the diagnosis of the disease in those cases in which the clinic and serology they are not enough ${ }^{5,39}$.

The results of the present study reflect that PL had a higher expression of the Ins/Del genotype (heterozygosity) (50.8\%), unlike the GC, showing that the Ins/Ins (31.25\%) and Del/Del (31.25\%) homozygous genotypes were the most frequent. Regarding the polymorphism at the allele level, it could be highlighted among the PL that the deletion allele is more frequent than the Ins allele, while the GC, both alleles were expressed in the same frequency. Observing an association between the Ins/Del heterozygous polymorphism, it presents a significant association of risk to SLE in our study population 
with an OR of 1.32, as well as the deletion allele, which is shown as a risk allele with an OR of 1.70, at difference of the Insertion allele that presents a significant association of protection to SLE with an OR of 0.59 .

A study carried out by Consiglio et al. ${ }^{24}$ in the Brazilian population, observed that after studying 195 PL against 122 apparently healthy individuals, an excess of heterozygosity (Ins/Del) of $53.9 \%$ in PL was evidenced, unlike the CG that presented a 50\% heterozygosity. Without noting any statistically significant results regarding genotypes, however, these authors observed a slight increase of the Ins allele in PL versus GC. Like the work carried out by $\mathrm{Wu}$ et al. ${ }^{28}$ that described a lack of association between the $14 \mathrm{bp}$ Ins/Del polymorphism in the 3'UTR untranslated region of the HLA-G gene in SLE in Chinese patients.

The results of these studies lead us to believe that patients who carry the Ins allele in their genotype have low levels of HLA-G, which affects the regulatory functions of this protein on certain cells of the immune system, such as: the inhibition of the cytotoxic activity of $\mathrm{T}$ and NK lymphocytes, the induction of apoptosis of activated CD8 $\mathrm{T}$ cells and NK, which, when the disease is triggered by an environmental factor and the compromised immune system cannot be adequately regulated. In this way, the association between the presence of the Ins/Del allele could be explained ${ }^{3,40}$.

After evaluating the role of polymorphism in the 3'UTR region of HLA-G with susceptibility to SLE, it was evaluated whether any of the genotypes and / or alleles is associated as a risk factor to clinical manifestations observed in the patients who participated in the study. Patients were stratified according to whether or not they presented a certain parameter clinical, this in order to find some genetic associa69 tion that provide us with information about the clinical complications that may occur in patients.

The characteristic onset of the disease can be described with asthenia, arthralgias, malar erythema, variable febrile syndrome, weight loss, general malaise, headache and other potential manifestations, such as pleuritic pain, abdominal pain, lupus nephritis, especially in young women ${ }^{1}$.

Figure 1 shows that the signs and symptoms most frequently reported by patients during their illness were: general discomfort (75.9\%), arthritis (65.7\%), blood problems $(59.6 \%)$, oral ulcers $(52.5 \%)$, malar erythema (44.1\%) and kidney problems (39\%). In a majority of cases the initial condition was multisystemic (more than one clinical sign or symptom at the same time), which made its initial diagnosis difficult.

In a group of 1000 European patients, the main clinical manifestations at the beginning and during the evolution of the disease were: malar erythema, discoid lesions, subacute skin lesions, photosensitivity, oral thrush, arthritis, serositis and renal problems ${ }^{5,41}$. The results of the present study showed that the main risk factors for suffering hematological manifestations in LP are the Del/Del genotype. Making a comparison with international literature, the data correlates with the findings made by Rizzo et al. ${ }^{19}$, Who also reported that patients homozygous for the deletion allele frequently reported hematologic involvement and had lower plasma levels of sHLA-G compared with patients who did not have a hematological condition.

Given that the main hematological manifestations are due to anti-platelet and anti-erythrocyte antibodies, and that HLA-G shows an inhibitory effect on B lymphocytes, it is believed that the low concentration of sHLA-G in patients with hematological symptoms favors the production of autoantibodies, 
which predisposes to suffer hematological manifestations in patients with SLE ${ }^{16,42}$.

Regarding dermatological manifestations in the present study is associated that the heterozygous Ins/Del genotype represents a risk factor, in general this group of patients reported presenting signs of malar erythema and photo sensitivity at the beginning of the study ${ }^{41}$.

In the study carried out by Cavalcanti et al. ${ }^{20}$, in Brazilian patients diagnosed with SLE in childhood, they showed that the Del allele and the Del/Del genotype show an association with lupus nephritis.

In the present study, what was evidenced in the results was that the Ins allele is presented as a protection factor for renal manifestations. In conclusion, the genetic association is established in the study population (given the miscegenation) and in La Paz population, in particular the Ins/Del polymorphism of a $14 \mathrm{bp}$ fragment in the 3 UTR region of the gene encoding the HLA-G protein, is a genetic risk factor for suffering from SLE and have a higher risk of suffering from some of its clinical manifestations such as dermatological and hematological when the patient presents the Ins/Del and Del/Del genotypes respectively.

Therefore, it is recommended to continue carrying out studies in the field of immunogenetics that allow the search for genes with high values of predisposing risk factor (Odds ratio, relative risk, etc.) and allow predicting the risk of suffering SLE or that with a high level of confidence predict which organ or system in the patient will be affected by the disease.

\section{Funding Source}

The present study was financed with resources from the Direct Tax on Hydrocarbons (HDI) 2010-2011 management of the Universidad Mayor de San Andrés, as part of the competitive project "Determination of the genetic association of the polymorphisms of the gene that encode the angiotensin-converting enzyme, the HLA-loci DR and HLA-DQ with susceptibility to Systemic Lupus Erythematosus"

\section{Conflicts of interest}

The authors express that there are no conflicts of interest regarding the research, authorship and / or publication of this article.

\section{Acknowledgments}

Firstly, I thank my thesis advisor Dr. Luis Fernando Sosa Tordoya for giving me all his scientific knowledge and giving me the opportunity to be part of the project. My thanks too it is addressed to the Bolivian Association against Lupus (ASBOLUP), since without their collaboration this work would not have been carried out.

\section{Ethical aspects}

The present work was evaluated by the research ethics committee of the Universidad Mayor de San Andrés under international regulations on research ethics (CIOMS / WHO Guidelines, Helsin-ki / AMM) which includes the ethical criteria that must be take into account for research involving human beings.

All participants in this work authorized and signed an informed consent. Protection of people and animals. The authors declare that for this research they did not perform experiments on humans or animals. 
Confidentiality of the data. The authors declare who have followed the protocols of their workplace on the publication of patient data.

Right to privacy and informed consent. The authors declare that no patient data appear in this article.

\section{Literature cited}

1. Mejía Salas H, Mendoza Amatller A. Lupus eritematoso sistémico. Rev Bol Ped 2004;43(1): 44-5.

2. Enriquez Mejia M. Fisiopatologia del lupus eritematoso sistémico. Revista de Medicina e Investigación 2013;1(1):8-16.

3. Anaya JM, Tobón GJ, Pineda Tamayo R, Fond J, Cervera R. Lupus eritematoso sistemico. En: Anaya JM, Shoenfeld Y, Correa PA, García Carrasco M, Cervera R, editores. Autoinmunidad y Enfermedad Autoinmune. Coorporacion para Investigaciones Biologicas; 2005. p. 255-73. Recuperado a partir de: https://www.academia. edu/36483902/Autoinmunidad_y_Enfermedad_A utoinmune

4. Bermúdez Marrero WM, Vizcaino Luna Y, Bermúdez Marrero WA. Lupus eritematoso sistémico. Rev Méd Cent Hosp [Internet].2017 [citado 5 de octubre de 2019];11(1):82-95. Recuperado a partir de: http://www.revacta medicacentro.sld.cu/index.php/amc/article/view/795/981

5. Gómez Puerta JA, Cervera R. Lupus eritematoso sistémico. Medicina \& Laboratorio [Internet]. 2008 [citado 5 de octubre de 2019];14(5-6):21123. Recuperado a partir de: https://www. medigraphic.com/pdfs/medlab/myl-2008/myl0856b.pdf
6. Tsokos GC. Systemic lupus erythematosus. N Engl J Med 2011;365:2110-21. DOI: http://doi. org/10.1056/NEJMra1100359

7. Navarrete CL, Ibañez C. Rol de la apoptosis en la fisiopatología del lupus. Rev Chil Reumatol 2008;24(1):30-8.

8. Kamen DL. Environmental influences on systemic lupus erythematosus expression. Rheum Dis Clin North Am 2014;40(3):401-12. DOI: https:// doi.org/10.1016/j.rdc.2014.05.003

9. Tsokos GC, Lo MS, Costa Reis P, Sullivan KE. New insights into the immunopathogenesis of systemic lupus erythematosus. Nat Rev Rheumatol 2016;12(12):716-30. DOI: https://doi. org/10.1038/nrrheum.2016.186

10.Severiche Maury DM, Restrepo Escobar M, González Naranjo LA, Vanegas García AL, Muñoz Vahos CH, Vázquez Duque GM. Ciento quince pacientes con lupus eritematoso sistémico: características clínicas e inmunológicas. Rev Colomb Reumatol 2014;21(4):183-92. DOI: https://doi.org/10.1016/j.rcreu.2014.10.002

11.Agmon Levin N, Damoiseaux J, Kallenberg C, Sack U, Witte T, Herold M, et al. International recommendations for the assessment of autoantibodies to cellular antigens referred to as anti-nuclear antibodies. Ann Rheum Dis 2014;73(1):17-23. DOI: https://doi.org/10.1136/ annrheumdis-2013-203863

12.Ruiz Narvaez EA, Fraser PA, Palmer JR, Cupples LA, Reich D, Wang Y, et al. MHC region and risk of systemic lupus erythematosus in African-American women. Hum Genet 2011;130(6):807-15. DOI: https://doi.org/10. 1007/s00439-011-1045-2

13.Alarcón Segovia D, Alarcón Riquelme ME, Cardiel MH, Caeiro F, Massardo L, Villa AR, et al. Familial aggregation of systemic lupus 
erythematosus, rheumatoid arthritis, and other autoimmune diseases in 1.177 lupus patients from the GLADEL cohort. Arthritis Rheum 2005;52(4):1138-47. DOI: https://doi.org/10.10 02/art.20999

14. Arrazola García MA. Tipificación de los alelos HLA clases I y II. Rev Med Inst Mex Seguro Soc 2005;43 (Supl 1):S95-97.

15.Vega Robledo GB. Complejo mayor de histocompatibilidad. Rev Fac Med UNAM [Internet]. 2009 [citado 5 de octubre de 2019];52(2):86-9. Recuperado a partir de: https://www.medigraphic.com/pdfs/facmed/un2009/un092j.pdf

16.Costa Reis P, Sullivan KE. Genetics and epigenetics of systemic lupus erythematosus. Curr Rheumatol Rep 2013;15(9):369. DOI: https://doi.org/10.1007/s11926-013-0369-4

17.Alfonso Valdes ME. HLA-G: ¿molecula inductora de inmunotolerancia? Rev Cuba Hematol Inmunol Hemoter 2009;25:8-17.

18. Rincon V, Manrique E. HLA-G: Su importancia inmunologica. Nova 2006;4(5):91-9. DOI: https://doi.org/10.22490/24629448.352

19. Rizzo R, Hviid TV, Govoni M, Padovan M, Rubini M, Melchiorri L, et al. HLA-G genotype and HLA-G expression in systemic lupus erythematosus: HLA-G as a putative suscep tibility gene in systemic lupus erythematosus. Tissue Antigens 2008;71(6):520-9. DOI: https:// doi.org/10.1111/j.1399-0039.2008. 01037.x

20.Cavalcanti A, Almeida R, Mesquita Z, Duarte ALBL, Donadi EA, Lucena Silva N. Gene polymorphism and HLA-G expression in patients with childhood-onset systemic lupus erythe matosus: A pilot study. HLA 2017;90(4): 217-27. DOI: https://doi.org/10.1111/ tan.13084

21.Foroni I, Couto AR, Bettencourt BF, Santos M, Lima M, Bruges Armas J. HLA-E, HLA-F and
HLA-G - The non-classical side of the MHC cluster. In: Foroni I, Couto AR, Bettencourt BF, Santos M, Lima M, Bruges Armas J, editors. HLA and Associated Important Diseases. IntechOpen; 2014. p. 61-109. Recuperado a partir de: https://pdfs.semanticscholar.org/6ea6/66beadf 28a113de62756482af197d5c5f41a.pdf

22.Nomenclature for Factors of the HLA System [Internet]. Nomenclature. 1987 [citado 5 de enero de 2018]. Recuperado a partir de: http://hla. alleles.org/nomenclature/index.html

23.Dias FC, Castelli EC, Collares CV, Moreau P, Donadi EA. The role of hla-g molecule and hla-g gene polymorphisms in tumors, viral hepatitis, and parasitic diseases. Front Immunol 2015;6:9. DOI: https://doi.org/10.3389/fimmu.2015.00009

24.Consiglio CR, Veit TD, Monticielo OA, Mucenic T, Xavier RM, Brenol JCT, et al. Association of the HLA-G gene $+3142 \mathrm{C}>\mathrm{G}$ polymorphism with systemic lupus erythematosus. Tissue Antigens 2011;77(6):540-5. DOI: https://doi.org/10.1111/ j.1399-0039.2011.01635.x

25.Veit TD, Chies JA. Tolerance versus immune response-microRNAs as important elements in the regulation of the HLA-G gene expression. Transpl Immunol 2009;20(4):229-31. DOI: https: // doi.org/10.1016/j.trim.2008.11.001

26. Grange C, Camussi G. Immunosuppressive role of extracellular vesicles: HLA-G, an important player. Ann Transl Med 2017;5(10):223. DOI: https://doi.org/10.21037/atm.2017.03.61

27.Rousseau P, Le Discorde M, Mouillot G, Marcou C, Carosella ED, Moreau P. The 14 bp deletioninsertion polymorphism in the 3' UT region of the HLA-G gene influences HLA-G mRNA stability. Hum Immunol 2003;64(11):1005-10. DOI: https://doi.org/10.1016/j.humimm.2003.08.347

28. Wu FX, Wu LJ, Luo XY, Tang Z, Yang MH, Xie $\mathrm{CM}$, et al. Lack of association between HLA-G 
14-bp polymorphism and systemic lupus erythematosus in a Han Chinese population. Lupus 2009;18(14):1259-66. DOI: https://doi.org/ 10. $1177 / 0961203309345756$

29.Hviid TV, Hylenius S, Hoegh AM, Kruse C, Christiansen OB. HLA-G polymorphisms in cou ples with recurrent spontaneous abortions. HLA Inmune Response Genetcs, Tissue Antigens 2002;60(2):122-32. DOI: https://doi.org/10.10 34/j. 1399-0039.2002.600202.x

30.Cozzani E, Drosera M, Gasparini G, Parodi A. Serology of Lupus Erythematosus: Correlation between Immunopathological Features and Clinical Aspects. Autoimmune Dis 2014;2014: 321359. DOI: https://doi.org/10.1155/ 2014/3213 $\underline{59}$

31.Medicina Familiar. Nuevos criterios de clasificacion para el Lupus Eritematoso Sistemico [Internet]. Escuela de Medicina. 2020 [citado 20 Junio 2019]. Recuperado a partir de: https://medicina.uc.cl/publicacion/nuevos-crite rios-de-clasificacion-para-el-lupus-eritematososistemico/

32. Aringer M, Dörner T, Leuchten N, Johnson SR. Toward new criteria for systemic lupus erythematosus-a standpoint. Lupus 2016;25(8): 805-18. DOI: https://doi.org/10.1177/ 096120331 $\underline{6644338}$

33.Favorgen Biotech Corp._FavorPrep ${ }^{\mathrm{TM}}$ 96-well Gel/ PCR Clean-Up DNA Kit. [monografía en Internet]. Australia: Australian distributors: Fisher Biotec Australia; 1997 [acceso 12 de junio de 2019]. Disponible en: https://www.fisherbiotec. com.au/wp-content/uploads/2019/03/Favorgen96well-Gel-PCR-Cleanup-14Mar19.pdf

34.Rodríguez Tarduchi G. Cuantificación de ácidos nucleicos. [monografía en Internet]. Madrid: Fundación Parque Científico de Madrid;2014 [acceso 23 de agosto de 2019]. Disponible en: https://www.iib.uam.es/portal/documents/76122/ 76162/CUANTIFICACION+DE+\%C3\%81CID OS+NUCLEICOS+V2.pdf/04333940-c6ff-4419ad85-cfd1e04dbca8

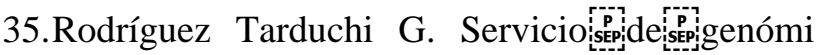

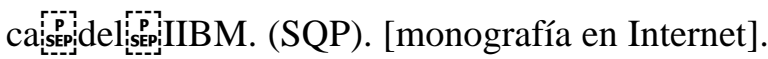
Madrid: Fundación Parque Científico de Madrid; 2014 [acceso 22 de junio de 2020]. Disponible en: https://www.fisherbiotec. com.au/wp-content/ uploads/2019/03/Favorgen-96well-Gel-PCRCleanup-14Mar19.pdf

36. Castañeda JA, Gil Laverde JF. Una mirada a los intervalos de confianza en investigación. Rev Colomb Psiquiatr 2004;33(2):193-201.

37.Cárdenas Roldán J, Rojas Villarraga A, Anaya JM. How do autoimmune diseases cluster in families? A systematic review and meta-analysis. BMC Med 2013:11:73. DOI: https://doi.org/ $\underline{10.1186 / 1741-7015-11-73}$

38.Pérez W. En La Paz se detectan cada año a 130 personas con lupus. La Razón. Martes 13 de mayo de 2014; Sociedad. Recuperado a partir de: http://www.la-razon.com/sociedad/EnfermedadLa Paz-detectan-ano-personas-lupus $0 \quad 20511$ 94905.html

39.Cozzani E, Drosera M, Gasparini G, Parodi A. serology of lupus erythematosus: correlation between immunopathological features and clinical aspects. Autoimmune Dis 2014;2014: 321359. DOI: https://doi.org/10.1155 /2014/32 $\underline{1359}$

40.Donadi EA, Castelli EC, Arnaiz Villena A, Roger M, Rey D, Moreau P. Implications of the polymorphism of HLA-G on its function, regulation, evolution and disease association. 
Cell Mol Life Sci 2011;68(3):369-95. DOI: https://doi.org/10.1007/s00018-010-0580-7

41. Velásquez Franco CJ, Anaya Prada A, Rodríguez Padilla LM, Vargas Grajales FI, Ramírez Gómez LA. Manifestaciones cutáneas de lupus eritemaEditor's Note: Journal of the Selva Andina Research Society (JSARS) remains neutral regarding jurisdictional claims published on maps and toso sistémico temprano y correlación con la acinstitutional affiliations.

tividad sistémica. Iatreia 2011;24(4):359-64.

42.Liu A, La Cava A. Epigenetic dysregulation in systemic lupus erythematosus. Autoimmunity 2014;47(4):215-9. DOI: https://doi.org/10.3109/ $\underline{08916934.2013 .844794}$ 